\title{
Strategi Tabligh Gus Nur
}

\author{
Sarah Maesaroh* \\ Jurusan Komunikasi dan Penyiaran Islam, Fakultas Dakwah dan Komunikasi, \\ UIN Sunan Gunung Djati Bandung \\ *Email:sarah.maesaroh@student.uinsgd.ac.id
}

\section{ABSTRAK}

Tulisan ini menjelaskan tentang perencanaan Gus Nur terhadap tabligh dengan menggunakan media kuburan, aktualisasi/pelaksanaan kegiatan tabligh, dan bagaimana feedback dari kegiatan tabligh Gus Nur. Peneliti menggunakan metode analisis deskriptif dengan pendekatan kualitatif. Dari hasil penelitian bahwa perencanaan Gus Nur meliputi pengenalan khalayak sehingga pesan yang disampaikan dapat mempengaruhi jamaah, menggunaan media serta metode yang memiliki keselarasan dapat mengundang perhatian jamaah. Pelaksanaan tabligh yakni berupa ceramah dari podium yang dilanjut di dalam kubur dengan penggunaan kain kafan dan keranda sebagai visualisasi orang meninggal. Feedback yang diterima berbentuk feedback seketika dan tertunda yang bersifat positif dan negatif. Adapun feedback positif yang diterima yakni mengucapkan terimakasih kepada Gus Nur yang menjadi jalan hidayah Allah sehingga bertaubat. Feedback negatif berupa tudingan sihir, bid'ah, syirik, kafir dan menyesatkan. Dari feedback yang muncul, beliau jawab dari buku "Dakwah dari dalam Kubur" dan facebook "Gus Nur Ngaji Bareng".

Kata Kunci : Strategi, Tabligh, Media Tabligh

\section{ABSTRACT}

This paper discusses the planning of Gus Nur against the tabligh by using the grave media, actualization / implementation of tabligh activities, and how the feedback from the activities tabligh Gus Nur. Researchers use descriptive analysis method with qualitative approach. From the result of research that Gus Nur planning include the introduction of audience so that message delivered can influence congregation, use media and method that have harmony can invite attention of pilgrims. Implementation of tabligh in the form of lectures from the podium continued in the grave with the use of shroud and keranda as a visualization of the dead. Feedback received in the form of 
Sarah Maesaroh

instantaneous and delayed feedback that is positive and negative. The positive feedback received is to thank Gus Nur who became the way of Allah's guidance so repent. Negative feedback in the form of accusations of magic, heresy, shirk, kafir and misleading. From the feedback that appears, he replied from the book "Da'wah from within the Grave" and facebook. "Gus Nur Ngaji Bareng".

Keywords: Strategy, Tabligh, Tabligh Media.

\section{PENDAHULUAN}

Tabligh merupakan kegiatan dakwah dengan menggunakan lisan atau tulisan. Tabligh tidak hanya cukup disampaikan oleh lisan belaka. Media dapat mendukung berjalannya tabligh yang menjadi saluran penghubung antara ide dan umat yang menjadi elemen vital seerta urat nadi kegiatan tabligh.

Dari kegiatan tabligh, para mubaligh lumrah menggunakan metode dan media yang sudah dikenal orang banyak seperti menggunakan mimbar, podium, radio, televisi bahkan internet. Berbeda dengan mubaligh asal Probolinggo bernama panggilan Gus Nur, dalam kegiatan tablighnya mengundang banyak orang yang penasaran karena metode yang digunakan ceramah di dalam kubur/tanah.

Penelitian dilakukan ditempat diadakannya tabligh yakni di Dusun Selacai, Selamanik Kecamatan Cipaku Kabupaten Ciamis - Jawa Barat pada tanggal 24 Januari 2016.

Adapun pertanyaan penelitian sebagai berikut: bagaimana perencanaan Gus Nur terhadap tabligh dengan menggunakan media kuburan?, bagaimana aktualisasi / pelaksanaan kegiatan tabligh?, bagaimana feedback dari kegiatan tabligh Gus Nur?

Penelitian ini memilih metode deskriptif, sebagai pendekatan yang digunakan. Metode deskriptif dianggap penulis dapat membantu dalam mencari fakta dengan interpretasi yang tepat. Dengan menggunakan metode penelitian deskriptif, penulis dapat menggambarkan masalah dengan cara memaparkan apa adanya yang berhubungan dengan proses kegiatan tabligh. Penelitian ini termasuk jenis analisis kualitatif, yakni penelitian ini menghasilkan penemuan-penemuan yang tidak dapat diperoleh melalui prosedur statistik (pengukuran) atau bentuk hitungan lainnya.

\section{LANDASAN TEORITIS}


Tabligh merupakan bentuk kegiatan dakwah yang lebih spesifik. Tabligh merupakan bentuk dakwah dengan cara menyampaikan ajaran Islam yang secara umum menggunakan media mimbar dan media massa (elektronik atau cetak) dengan sasaran banyak orang.

Secara bahasa, Tabligh berasal dari kata balagha, yuballighu, tablighan, yang berarti menyampaikan. Tabligh adalah kata kerja transitif, yang berarti membuat seseorang sampai, menyampaikan, atau melaporkan, dalam arti menyampaikan sesuatu kepada orang lain (Enjang, Aliyudin, 2009: 53).

Dari segi makna istilah, tabligh didefinisikan sebagai sebuah proses penyampaian pesan dari satu pihak ke pihak lain dengan tujuan terciptanya persepsi yang sama tentang pesan tersebut. Dalam term umum, tabligh sering diderivasikan dengan istilah komunikasi dengan salah satu ciri efeknya adalah adanya feedback positif dari pihak komunikan terhadap pesan tersebut. Dalam aktifitas dakwah, tabligh berarti menyampaikan ajaran Islam kepada orang lain (Fatoni, 2003: 35).

Tujuan tabligh sama halnya dengan tujuan dakwah yakni menyampaikan ajaran Allah yang berpedoman kepada Alquran dan Sunnah guna mencapai kebahagiaan dunia dan akhirat. Sasaran tabligh pun sama dengan sasaran dakwah yaitu umat manusia.

Dalam buku Kisi-Kisi Materi Ujian Komprehensif Fakultas Dakwah dan Komunikasi UIN Sunan Gunung Djati Bandung (2016: 35) tujuan tabligh Islam ialah meningkatkan kesejahteraan masyarakat, meninggi-kan akal fikiran, hati dan perilaku, menyebarkan kebudayaan Islam dengan nilai-nilai yang luhur, berusaha menyatukan hingga mengikat umat secara pikiran dan perasaan, kesatuan serta keharmonisan sesama kaum muslim dan memusahkan isolasi diantara mereka. Inti dari tujuan tabligh diatas ialah mengubah pandangan hidup seseorang sehingga berubah pola pikir dan sikap.

Tujuan tabligh secara umum adalah mengubah perilaku masyarakat agar mau menerima ajaran Islam dan mengamalkannya dalam kehidupan sehari-hari, baik yang bersangkutan dengan masalah pribadi, keluarga maupun masyarakat sosial. Supaya terdapat kehidupan yang penuh dengan keberkahan serta terbebas dari api neraka.

Sebagaimana firman Allah SW'T dalam QS. Al-A'raf : 96

"Jika sekiranya penduduk negeri-negeri beriman dan bertaqwa, pastilah kami akan melimpahkan pada mereka berkah dari langit dan bumi tetapi mereka mendustakat (ayat-ayat) kami itu, maka kami siksa mereka disebabkan perbuatan mereka” (Depag RI, 2014: 163). 
Menurut Endang Saifudin Anshari (1986: 192) tujuan tabligh identik dengan tujuan hidup seorang muslim: tujuan vertikal: Allah yakni mendapat keridhoan-Nya, tujuan Horizontal: Rahmat bagi segenap alam yakni, tujuan sebagai individu, Tujuan sebagai anggota keluarga, tujuan sebagai warga lingkungan, tujuan sebagai bangsa, dan tujuan sebagai warga dunia sertatujuan sebagai warga universal

Dari uraian diatas dapat disimpulkan bahwa tujuan tabligh berhubungan dengan tujuan hidup manusia. Seseorang yang telah memiliki pemahaman bahwa tujuan hidup ini adalah meraih kemualiaan, maka seluruh pemikiran, perkataan dan tindakan akan mengarah kepada jalan kebaikan.

Adapun tujuan dakwah menurut Ahmad Soebandi (1994: 60), secara hirarki memiliki dua tujuan, yakni tujuan utama dan departemental. Tujuan utamanya adalah terwujudnya kesejahteraan dan kebahagiaan hidup di dunia dan akhirat yang diridhoi Allah SWT, sedangkan tujuan departemental dakwah adalah tujuan-tujuan yang bersifat sementara karena didalamnya berisikan nilai-nilai yang dapat mengantarkannya kepada kesejahteraan dan kebahagiaan yang di ridhoi Allah SWT berdasarkan bidangnya masing-masing.

Maka dapat disimpulkan bahwa tujuan tabligh memiliki satu keterpaduan dengan tujuan dakwah. Hal ini dikarenakan tujuan tabligh merupakan dimensi dalam lingkup dakwah.

Al-Qur'an dan Sunnah menjadi dasar hukum tabligh dan para ulama sepakat dalam menetapkan hukum tabligh adalah wajib. Hal ini sesuai perintah Allah SWT yang berfirman dalam QS. Al-Maidah ayat 67:

"Hai Rasul! Sampaikanlah apa yang diwahyukan kepada engkau dari

Tuhan. Dan kalau tidak engkau kerjakan, maka berarti engkau tidak menyampaikan tugas perutusan dari Allah. Allah memelihara engkau dari manusia. Sesugguhnya Allah tidak memberi petunjuk kepada kaum yang tidak beriman" (Depag RI, 2014: 119).

Quraish Shihab menafsirkan, bahwa ayat ini mengingatkan Rasul akan kewajibannya menyampaikan ajaran agama yakni petunjuk Allah yang diturunkan kepada Ahli Kitab tanpa menghiraukan kritik dan ancaman mereka yang disertai dengan jaminan keamanan beliau, dan apabila tidak dikerjakan apa yang diperintahkan walau hanya meninggalkan sebagian kecil dari apa yang harus engkau sampaikan, maka ia berarti tidak menyampaikan amanah-Nya secara menyeluruh ( $2005: 152)$.

Dalam Qur'an Surat Yasin : 17 
"Dan kewajiban kami hanyalah menyampaikan (perintah Allah) dengan jelas” (Depag RI. 2014: 441).

Hukum wajib juga diperkuat oleh hadits Rasulullah SAW riwayat Imam Muslim, yang berbunyi:
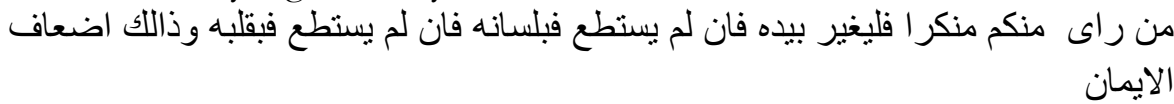

"Siapa saja melihat kemunkaran maka rubahlah dengan tangannya, jika tidak mampu maka dengan lisannya, dan jika tidak mampu maka rubahlah dengan hatinya, dan yang demikian (merubah dengan hati) merupakan selemah-lemahnya iman" (Aliyuddin: 41 Shahih Muslim, no 45).

Berikut juga riwayat at-tirmidzi, hadits tentang setiap muslim diwajibkan bertabligh sesuai dengan kemampuan dan ilmu yang dimilikinya:

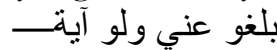

"Sampaikanlah apa-apa dari aku, walaupun hanya satu ayat"

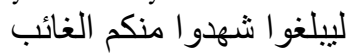

"Agar yang hadir menyampaikan kepada yang tidak hadir"

Maka dapat disimpulkan bahwa tabligh hukumnya wajib bagi setiap orang yang menganut agama Islam untuk menyampaikan ajaran Islam sesuai dengan kemampuan yang dimilikinya.

Menurut Aliyuddin, apabila mengacu kepada definisi dan contoh tabligh yang dilakukan Rasulullah SAW dapat dibagi menjadi dua, yaitu tabligh melalui lisan (khitobah) dan melalui tulisan (kitabah). Aang Ridwan dalam Jurnal Ilmu Dakwah Vol. 5 No. 1 menambahkan I'lam sebagai kegiatan tabligh.

خطب - يخطب - Dari segi bahasa khitobah berasal dari akar kata: خطبة)(khataba, yakbtubu, khutbatan atau khitobatan) yang berarti; berkhutbah, pidato, meminang, melamar, bercakap-cakap atau mengirim surat. Dalam Kamus Besar Bahasa Indonesia khitobah memiliki sinonim dengan pidato, terutama menguraikan sesuatu ajaran Islam (Poerwadarminta, 1985: 985). Atas makna ini, Aliyudin mengutip terminology khitobah yang dikemukakan oleh Harun Nasution dan Al-Jurjani (Aliyudin, 2009: 57). Menurut Nasution, khitobah adalah ceramah atau pidato yang mengandung penjelasan-penjelasan tentang sesuatu atau beberapa masalah yang disampaikan seseorang dihadapan sekelompok orang atau khalayak. Sedangkan menurut Al-Jurjani khitobah adalah sebagai suatu upaya menimbulkan rasa ingin tahu terhadap orang lain tentang suatu perkara 
yang berguna baginya baik mengenai urusan dunia maupun akhirat.

Berdasarkan terminologi diatas, secara ontologis khitobah dapat diartikan sebagai upaya sosialisasi nlai-nilai Islam melalui media lisan yang kerap dalam prosesnya melibatkan unsur khatib sebagai subyek, materi atau pesan, metode, media, dan jama'ah, yang dilakukan dalam ruang dan waktu tertentu hingga mencapai kepada tujuannya yakni menciptakan umat yang berkualitas.

Dari segi pelaksanaannya khitobah ini terbagi menjadi dua bentuk, yaitu khitobah diniyah dan khitobah ta'tsiriyah. Khitobah diniyah adalah khutbah yang terikat langsung dengan pelaksanaan ibadah mahdhah dan bahkan menjadi syarat syahnya ibadah mahdhah. Khitobah diniyah memiliki keterkaitan sangat ketat dengan aturan syariab yang bersifat ta'abudi. Diantara khitobah diniyah adalah; khutbah jum'at, khutbah idain, khutbah khusuf, khutbah istiqra dan khutbah saat wuquf di Arafah.

Karena keterkaitannya dengan ibadah mahdhah, maka yang menjadi khotib bukanlah orang sembarangan melainkan orang yang sudah memenuhi kriteria yang ditentukan dalam fiqih ibadah yang didasarkan pada al-Qur'an, Sunnah dan Ijma Ulama.

Ciri-Ciri khitobah Diniyah menurut Aang Ridwan (2011: 206-207), sebagai berikut:

Tabel 1 Ciri-ciri Khitobah Diniyah

\begin{tabular}{ll}
\hline Unsur Khitobah & \multicolumn{1}{c}{ Ciri-Ciri } \\
\hline Subjek & Mukallaf \\
& Harus memenuhi syarat yang ditetapkan dalam ketentuan fiqih Ibadah \\
& Dihajatkan mampu menjadi Imam \\
Struktur materi bersifat baku & Eksplorasi dan elaborasi materi bersifat informatif, edukatif dan \\
& dihajatkan bersifat normatif theologik \\
& Isi materi merujuk dan mengkerucut pada peningkatan kualitas iman \\
& dan taqwa \\
Metode & Durasi penyampaian materi terbatas \\
& Monolog tanpa teks \\
Media & Monolog dengan membaca teks yang ditulis secara utuh \\
Tempat & Monolog membaca teks yang bersifat pointer \\
& Mimbar \\
Waktu & Masjid \\
Objek & Lapangan \\
Feed back & Permanen (tetap dan ditentukan syariah) \\
& Mukmin mukallaf \\
& Tidak langsung
\end{tabular}


Posisi Pengiring ibadah mahdhah

Penentu syah tidaknya ibadah mahdhah

Suasana Sakral dan khidmat

Sifat Global (tidak terbatas ruang, dilakukan oleh muslim di wilayah manapun)

Selanjutnya, khitobah ta'tsiriyah yang berarti khitobah atau lebih dikenal dengan sebutan ceramah yakni pengiring kegiatan keagamaan yang bersifat ghoer mahdhah. Khitobah ini tidak terikat dengan ibadah mahdhah, kegiatannya seperti bergai tabligh akbar peringatan maulid Nabi, Isra Mi'raj, Nuzulul Qur'an, peringatan tahun baru 1 Muharram, tasyakur pernikahan, khitanan, aqiqah dan lain sebagainya.

Khitobah ta'tsiriyah memiliki karakter seremonial dan gemyar lebih semarak, sehingga dikenal luas dimasyarakat. Terlebih dengan dukungan pemakaian media-media komunikasi elektronik modern, seperti halnya disiarkan di stasiun televisi, radio, dan bahkan diperbanyak dalam bentuk kaset, VCD, DVD, dan lain-lain (Aliyuddin, 2009: 59).

Mengacu kepada jurnal Aang Ridwan mengenai ciri-ciri khitobah ta'tsiriyah sebagai berikut:

Tabel 2 Ciri-ciri Khitobah Ta’tsiriyah

\begin{tabular}{ll}
\hline \multicolumn{1}{c}{ Unsur Khitobah } & \multicolumn{1}{c}{ Ciri-ciri } \\
\hline Khotib / Mubaligh & Tidak meski seorang mukallaf (anak-anak diperkenankan) \\
(Subjek) & Syarat mubaligh tidak ketat merujuk pada ketentuan fiqih \\
& Dihajatkan profesional \\
Materi & Struktur materi tidak bersifat baku \\
& Eksplorasi dan elaborasi materi bersifat informatif, edukatif dan \\
& diperkenenkan agitatif dan rekreatif \\
& Dalam kbitobah ta'tsiriyah yang bersifat rutinan (majelis ta'lim) biasanya \\
& mengkaji literatur atau kitab tertentu \\
& Durasi penyampaian materi kondisional (bisa pendek atau panjang) \\
& Monolog \\
& Semidialog \\
Metode & Dialog \\
& Tidak lazim membaca teks secara utuh \\
& Mimbar \\
& Panggung \\
Media & Media massa elektronik \\
& Masjid \\
& Madrasah \\
Tempat & Stasiun televisi \\
& Stasiun radio \\
& Rumah
\end{tabular}

Tabligh: Jurnal Komunikasi dan Penyiaran Islam Vol. 1 No. 1 (2016) 65-86 
Sarah Maesaroh

\begin{tabular}{|c|c|}
\hline & Lapangan \\
\hline & Kondisional \\
\hline Waktu & Sesuai kebutuhan dan kondisi \\
\hline Objek & Heterogen (tua, muda, anak-anak, laki-laki, perempuan) \\
\hline Feedback & Langsung (tepuk tangan, tertawa, menangis atau marah) \\
\hline Posisi dan Fungsi & Pengiring atau penutup kegiatan ibadah ghair mahdhah \\
\hline & Kegiatan keagamaan yang bersifat primer \\
\hline & Kegiatan tambahan yang bersifat sekunder \\
\hline & Kegiatan yang bersifat suplementatif \\
\hline Suasana & Santai namun khidmat \\
\hline Sifat & $\begin{array}{l}\text { Lokal (dilakukan oleh komunitas masyarakat muslim di wilayah } \\
\text { tertentu) }\end{array}$ \\
\hline
\end{tabular}

Tabligh melalui tulisan (kitabah) yaitu proses penyampaian ajaran Islam melalui bahasa tulisan yang selanjutnya di terbitkan dalam bentuk majalah, novel, jurnal, buku, surat kabar, pamplet, brosur, blog dan lain sebagainya.

Dari kerangka sistem tabligh, i'lam berarti proses penyiaran dan penyebarluasan ajaran Islam baik secara lisan maupun tulisan dengan penggunaan media elektronik modern. Dalam makna yang lebih luas, i'lam dapat dipahami sebagai kegiatan penyiaran Islam dalam bentuk penyampaian informasi dan pengetahuan secara jelas dan hati-hati, berdasarkan hasil pertimbangan akal yang didasarkan pada pemahaman AlQur'an.

Strategi berasal dari bahasa Yunani yaitu kata "stragos" atau "strategis" dengan jamak strategi yang berarti jenderal, tetapi dalam Yunani kuno berarti perwira negara dengan fungsi yang luas (Salulu, 1985: 85). Strategi esensinya adalah suatu "gaya" berpikir yang pada awalnya hanya digunakan untuk kepentingan militer kemudian berkembang ke berbagai bidang.

Menurut kamus besar bahasa Indonesia strategi adalah (1) ilmu dan seni menggunakan semua sumber daya bangsa untuk melaksanakan kebijaksanaan tertentu dalam perang dan damai; (2) ilmu dan seni memimpin bala tentara untuk menghadapi musuh dalam perang, dalam kondisi yang menguntungkan; (3) rencana yang cermat mengenai kegiatan untuk mencapai sasaran khusus; (4) tempat yang baik menurut siasat perang (KBBI).

Menurut Husain Umar strategi berasal dari bahasa Yunani kuno yang berarti "Seni berperang". Menurutnya, strategi merupakan dasar-dasar atau skema untuk mencapai sasaran yang dituju, jadi pada dasarnya strategi merupakan alat untuk mencapai tujuan. Strategi merupakan tindakan yang bersifat meningkat dan terus menerus, serta dilakukan berdasarkan sudut 
pandang tentang apa yang telah diharapkan oleh orang lain dimasa depan, dan bisa dikatakan bahwa strategi merupakan rancangan atau rencana yang cukup matang dan benar-benar riel untuk mencapai tujuan (Asmuni Syukir, 1983 : 32).

Strategi merupakan sebuah perencanaan dalam sebuah management untuk mencapai suatu tujuan dengan tidak hanya menjadi petunjuk jalan saja melainkan menunjukan teknik operasionalnya.

Dari segi psikologi, strategi dianggap sebagai metode pengumpulan informasi dan pengorganisasiannya, sehingga bisa menaksirkan suatu hipotesis. Strategi dilakukan dengan melalui proses penelitian dengan cermat, sehingga dapat memilih tindakan-tindakan yang lebih efektif untuk mencapai sebuah tujuan. Dengan kata lain, strategi merupakan upaya pencapaian tujuan secara efektif dan efisien. Kustadi Suhandang (2014: 81 82) mengutip pendapat Littlejohn (1978: 72) yang menyamakan strategi dengan rencana suatu tindakan, dan metodenya yang sangat mendasar dikemukakan oleh Burke sebagai the dramatistic pentad (segi lima dramastik) yaitu: Act (aksi) yaitu berhubungan dengan aktor / subjek tentang apa yang harus dilakukan dan diselesaikan, Scene (suasana) yaitu tempat dilaksanakannya kegiatan dengan menjelaskan keadaan fisik maupun budaya dilingkungan masyarakat, Agent (agen) yaitu diri aktor yang akan melaksanakan tugasnya, Agency (agensi) yaitu media yang harus dan akan dipakai oleh aktor seperti saluran-saluran komunikasi, jalan pikiran, lembaga, cara, pesan, atau alat-alat terkait lainnya, dan Purpose (maksud) yaitu alasan bertindak, diantaranya mencakup tujuan teoretis, akibat atau hasil yang diharapkan dari sebuah kegiatan. (Kustadi Suhandang, 2014: 81 82)

Dari uraian diatas, kiranya dapat disimpulkan bahwa strategi merupakan rancangan atau design kegiatan (sebagai landasan berpijaknya pola tindak), dalam wujud penentuan dan penempatan semua sumber daya yang menunjang keberhasilan dalam pencapaian tujuan tertentu.

Adapun bentuk strategi, Djaslim Saladin (2004: 2) mengutip pendapat Gregory G. Dess dan Alex Miller (1993) yang membagi strategi dalam dua bentuk, yaitu strategi yang dikehendaki dan strategi yang direalisasikan.

Strategi yang dikehendaki (intended strategic) terdiri dari tiga elemen: 1) sasaran-sasaran (goals), yaitu menentukan tujuan yang ingin dicapai dari sebuah kegiatan. Sasaran ini memiliki tiga tingkatan: visi, merupakan kerangka acuan kegiatan nyata yang terpadu; Misi, yaitu banyaknya sasaran 
yang harus dicapai sebagai tugas dan prinsip utama guna mewujudkan visi; Tujuan-tujuan, yaitu tujuan-tujuan yang khusus dan spesifik harus dicapai demi terciptanya tujuan akhir yang telah ditentukan sebelumnya. 2) Kebijakan (policies), merupakan garis pedoman untuk bertindak guna mencapai sasaran dan 3) Rencana-rencana (plans), merupakan pernyataan dari tindakan terhadap apa yang diharapkan akan terjadi.

Adapun strategi yang direalisasikan (realized strategic) merupakan apa yang telah terwujud pencapaiannya. Strategi ini sering mengalami perubahan dalam keseluruhan implementasinya, sesuai dengan peluang dan ancaman yang dihadapinya. Strategi yang terwujud bisa mengalami kelebihan dan kekurangan dari strategi yang dikehendaki.

Melihat tujuan tabligh diatas, jelas memerlukan suatu strategi yang tepat guna. Tabligh merupakan proses dan metode komunikasi, maka tabligh memerlukan konsep dan strategi komunikasi yang jelas dan kondusif bagi keberhasilannya sehingga dapat memperkaya khazanah pengetahuan bidang dakwah dan bisa menolong para da'i dalam melaksanakkaan misinya.

Karena tabligh merupakan bagian dari dakwah maka dikutip pengertian strategi dakwah dari Syukir (1983: 32) yang artinya metode, siasat, taktik atau manuver yang dipergunakan dalam aktifitas dakwah untuk mencapai keberhasilannya secara maksimal.

Strategi tabligh merupakan proses komunikasi dan jika dilihat pengertiannya dari segi komunikasi yaitu sebagai suatu pola pikir dalam merencanakan suatu kegiatan mengubah sikap, sifat, pendapat, dan perilaku khalayak, atas dasar skala yang luas melalui penyampaian gagasan-gagasan (kustadi suhandang, 2014: 84).

Dari uraian diatas dapat disimpulkan strategi tabligh berarti kepiawaian seorang mubaligh dalam menangani sesuatu terkait metode dan pendekatan yang digunakan dalam mencapai tujuan yakni keberhasilan tabligh. Untuk itu, dalam proses menjalankan strategi tabligh, tentu kepekaan membaca situasi, karakter komunikan oleh da'i akan memiliki dampak cukup signifikan.

Untuk mencapai keberhasilan dakwah maupun tabligh, maka diperlukan berbagai faktor penunjang, diantaranya strategi tabligh yang tepat sasaran. Strategi yang digunakan dalam usaha dakwah haruslah memperhatikan beberapa asas dakwah, diantaranya adalah: 1) Asas filosofis: asas ini membicarakan masalah yang erat hubungannya dengan tujuan-ujuan yang hendak dicapai dalam proses atau aktivitas dakwah. 2) 
Asas kemampuan dan keahlian da'i: asas ini menyangkut pembahasan megenai kemampuan dan profesionalisme da'i sebagai subjek dakwah. 3) Asas sosiologi: Asas ini membahas masalah-masalah yang berkaitan dengan situasi dan kondisi sasaran dakwah. Misalnya politik pemerintah setempat, mayoritas agama disuatu daerah, filosofis sasaran dakwah, sosiokultural sasaran dakwah dan sebagainya. 4) Asas psikologi: asas ini membahas masalah yang erat hubungannya dengan kejiwaan manusia. Seorang da'i adalah manusia, begitu pula yang menjadi sasaran dakwah memiliki karakter unik dan berbeda satu saa lain. Pertimbangan-pertimbangan masalah psikologi harus diperhatikan dalam proses pelaksanaan dakwah. 5) Asas aktivitas dan efisien: didalam aktivitas dakwah harus diusahakan keseimbangan antara biaya, waktu, maupun tenaga yang dikeluarkan dengan pencapaian hasilnya dengan maksimal.

Dengan mempertimbangkan asas-asas diatas, seorang da’i hanya butuh memformulasikan dan menerapkan strategi dakwah yang sesuai dengan kondisi mad'u sebagai objek dakwah (Amin, 2009: 109-110).

Tabligh akan terus terlaksana oleh para pengembannya, mulai dari Rasulullah Saw. dilanjutkan oleh umatnya dengan metode dan pola yang terus berkembang sesuai dengan perkembangan jaman, perkembangan ilmu pengetahuan dan teknologi komunikasi.

\section{HASIL DAN PEMBAHASAN}

Gus Nur memiliki nama lengkap Sugi Nur Raharja lahir pada tanggal 11 Februari 1974 di desa terpencil daerah Banten dari pasangan suami istri Mutrokimah dan Abah Tomi. Gus Nur anak pertama dan memiliki adik bernama Dwi Nur Ningsih. Lahir dari keluarga pendekar dan hidup di lingkungan debus (ilmu kanuragan).

Usia 2 tahun hijrah ke Bantul Jogja bersama sang ibu (tempat lahir ibunya), kurang lebih hanya selama 3 tahun.Kemudian hijrah lagi ke Desa Gempeng,Kecamatan Bangil,Kabupaten Pasuruan, Jawa Timur. Menikah, memiliki rumah, dan pesantren di Probolinggo. Sejak disanalah beliau menjadi pengasuh pondok pesantren di Probolinggo 25-30 tahun.

Nama istri Gus Nur yakni Kuswati Nur'aini dan memiliki empat orang anak. Anak pertama bernama Nur Ika, anak kedua Muhammad Munziat, anak ketiga Syavira Putri Nur'aini dan anak bungsu bernama Afifah Syanum Muhbita (Data hasil wawancara tanggal 27 Juli 2016).

Pada tahun 2014 mendapat wakaf tanah di palu dan sekarang sedang dalam proses pembangunan untuk pondok pesantren yang diberi nama 
Sarah Maesaroh

Pesantren Tahfidz Qur'an Karomah 13. Keluarga diajak untuk berpindah dan tinggal menetap di Palu. Lokasinya sebagai jantung kota palu jaraknya 5 menit dari bandara.

Gus Nur mengaku belajar dari kehidupan. Beliau jadikan ustadz, kyai, pengemis, buku, kambing, ayam dan ilmu kehidupan lain sebagai gurunya yang tidak mengenal batas dengan beratap langit dan hamparan tanah. Beliau mengaku besar di jalan, bertemu ilmu agama dijalan, bertemu ilmu kehidupan dijalan yang menjadikan alam sebagai guru, angin sebagai dosen, dan pembimbingnya kehidupan nyata.

Karya-karyanya berupa buku diantaranya buku Dakwah dari dalam Kubur, Rahasia Karomah Angka 13, Belum Tentu..!, Hakikat MLM, 41 Helai Ilmu Hidup, Secuil Rahasia Karomah Surat Al-Fatihah, dan Kembali ke Jati Diri. Adapun karya menciptakan dan menyanyikan lagu-lagu nuansa islami salah satunya lagu berjudul Hijrah, Assalamu'alaykum, Istighfar, Ya Badrotim, dan Maula Ya Sholi.

Gus Nur memiliki kepribadian sangat sederhana, dari pengembaraannya ia banyak belajar dari kehidupan. Ia tidak memandang status manusia, baginya semua orang adalah guru yang memberikan manfaat. Pembelajaran yang tidak ada batas baginya sehingga ia belajar dari ilmu kehidupan.

Berbagai metode beliau telah gunakan dalam menyampaikan ajaran Islam diantaranya: melalui tulisan, nada, sastra, pakem fikih, kontemporer hilafiyah, tasawuf sufistik disiplin akademis / ladduni ijtihad, dan selaksa improve ladduni lainnya.

Beliau sangat mensyukuri karena Allah telah menanamkan sosok Emha Ainun Najib di hati Gus Nur sebagai guru ideologinya. Berikut penuturan Gus Nur saat di wawancarai penulis "Saya sangat bersyukur Allah kirim ideologi ke otak saya dengan sosok Cak Nun, beliau yang saya lihat orangnya apa adanya, tidak butuh popularitas, dan tidak mau disanjung" (wawancara, 24 Januari 2016).

Pemikiran Cak Nun yang spiral dan zig-zag yang digunakan Gus Nur dalam mencapai tujuan yang diinginkannya. Ilmu Cak Nun benar-benar di serap yakni selalu berontak dan mencari inovasi-inovasi baru.

Gus Nur memiliki sikap keterbukaan terhadap siapapun sehingga ia berhijrah pada jalan dakwah. Sikap keterbukaannya dilihat dari sikap selalu mengambil pelajaran dan motivasi dari orang lain termasuk Cak Nun yang dijadikan guru ideologinya.

Ia pun termasuk orang yang mau berbagi dan memiliki kepedulian 
sosial terhadap sesama. Sikap ini ia tunjukan dari menulis buku dan ceramah yang selalu ia unggah di facebook.

Selain itu ia pun seorang seniman, pemain debus pada awal sebelum mengenal dunia dakwah. Setelah terjun dunia dakwah, karakter seniman ia campurkan sebagai metode dakwah seperti melahirkan lagu-lagu bernuansa Islami.

Menurut Gus Nur kegiatan tabligh zaman sekarang telah terkalahkan oleh dangdut koplo. Ketika beliau diundang berceramah di suatu tempat dan di radius 2 kilometer diadakan dangdut koplo, maka yang datang ke pengajiannya itu tidak sebanyak mereka yang menghadiri dangdut koplo.

Dari alasan-alasan tersebut beliau berfikir untuk mencari inovasi dakwah yang baru agar dapat menarik manusia datang ke tempat pengajian. Hingga ia menemukan metode dakwah dalam kubur, menurut penulis lebih pas dengan sebutan ceramah di bawah tanah. Metode ini mulai diperkenalkan kepada masyarakat pada tahun 2002 dan berlangsung hingga saat ini. Pada saat itu tidak terpikir apa tujuannya yang terpenting baginya adalah mengajak dan menghadirkan sebanyak mungkin manusia untuk hadir dan mendengarkan pesan-pesan Islam.

Beliau mengaku bahwa di kubur hidup-hidup sudah menjadi alat pencari nafkah ketika beliau masih berprofesi sebagai seniman debus. Ditusuk, dibakar, semua sudah dilakukan untuk mencari makan.

Sebelumnya, Gus Nur mengaku pernah meniru dakwah ala Nabi Musa ketika bertemu dengan Fir'aun dan mengubah tongkat menjadi ular. Beliau berceramah dengan memawa tongkat dan mengubahnya menjadi ular. "Tapi orang-orang bilang itu rekayasa dan sihir" katanya. Pernah juga menerapkan dakwah ala Nabi Ibrahim yang dimasukkan ke dalam kobaran api dan dibakar. Mubalagh menganggapnya sedang bermain kuda lumping.

Pilihan ceramah dengan cara dikubur ini, menurut Gus Nur dilakukannya melalui proses panjang. Beliau merasa dampaknya terhadap ketentraman rumah tangganya yang kian menyayangi anak dan istrinya. "Dalam tiap hembus nafas ini, yang terasa hanya dekat mati saja dan sentuhannya lebih bermakna di sini" ujarnya.

\section{Perencanaan Tabligh Gus Nur}

Fungsi pertama dari strategi dakwah adalah sebuah perencanaan. Hal ini sesuai dengan hadits Nabi yang diriwayatkan oleh Umar bin Khatab : 
Sarah Maesaroh

"Saya mendengar Rasulullah bersabda, Wahai sekalian manusia, hanya segala amal dengan niat (menurut niat yang membangkitkan seseorang kepadanya). Dan hanya bagi manusia apa yang diniatkan. Maka barangsiapa yang hijrahnya kepada Allah dan Rasul-Nya, maka hijrahnya kepada Allah dan Rasu-Nya. Dan barangsiapa kepada dunia yang ia ingin memperolehnya, atau seseorang wanita yang ia ingin mengawininya, maka hijrahnya kepada apa yang ia berhijrah kepadanya itu" (Hasbi, 1955: 21).

Dengan demikian, sebuah perencanaan itu harus diawali dengan niat. Niat dimaksud hendaknya dilakukan dengan melaksanakan proses berpikir rasional, berdasarkan fakta dan data yang ada untuk dapat diambil langkahlangkah yang diperlukan guna mewujudkan tujuan yang ingin dicapai.

Sesuai firman Allah Swt. dalam QS. Al-Hasyr ayat 18:

"Wahai orang-orang yang beriman! Bertakwalah kepada Allah dan hendaklah setiap orang memperhatikan apa yang telah diperbuatnya untuk hari esok (akhirat), dan bertakwalah kepada Allah. Sungguh, Allah Mahateliti terhadap apa yang kamu kerjakan” (Depag RI, 2014: 548).

Allah mewajibkan manusia untuk memperhatikan apa yang hendak dilakukan, dalam arti yang tersirat adanya kewajiban merencanakan segala sesuatunya sebelum bertindak.

Perencanaan harus berpusat kepada data dan fakta yang dihadapinya dengan mengarah pada bentuk rumus $5 \mathrm{~W}+1 \mathrm{H}$, yang mencakup (Kustadi Suhandang, 2014 : 104-105): WHAT (APA) rencananya atau tujuan yang hendak dicapai; WHY (MENGAPA) yang menjadi pertanyaan ada sebab (apa sebabnya) yang menjadi tujuan; WHO (SIAPA), yang menjadi subjek pelaksana rencana tersebut; WHERE (DIMANA), yang menjadi tempat oprasinya; WHEN (KAPAN), waktu rencana itu akan dilaksanakan; HOW (BAGAIMANA), cara atau metode yang akan dilaksanakan.

Adapun rencana Tabligh Gus Nur ialah Seluruh aktivitas pasti memiliki sebuah tujuan yang menjadi sasaran utamanya. Tujuan dari tabligh Gus Nur mengubah seluruh aktivitas masyarakat kepada masyarakat madani yang ukhuwah Islamiyah, akhlakul karimah dan selalu menjaga serta menjalani kewajibannya. Bagi Gus Nur tujuan berdakwah beliau hanyalah Allah dan keridhaan-Nya (Data Wawancara tanggal 27 Juni 2016). Jika Allah sudah Ridha maka hidayah akan turun pada masyarakat khususnya pada diri pribadinya.

Melaksanakan kegiatan tabligh dengan dikafani dan dikubur 
mengingatkan akan kesadaran hidup manusia di dunia ini hanyalah sesaat dan alam kubur akan menjadi perjalanan selanjutnya seorang manusia.

Kegiatan tabligh dilakukan melalui undangan dari siapa saja kepada Gus Nur langsung dengan segala medan. Lokasi yang dipilih haruslah tepat karena memerlukan tempat yang besar untuk menampung ribuan jamaah yang hadir. Waktunya pun tidak bisa mendadak, penetapan waktu disepakati tiga bulan sebelum hari berlangsungnya kegiatan tabligh.

Dari segi aktivitas kegiatan tabligh menggunakan bahasa lisan dan dalam tataran teknis menggunakan metode ceramah yang bersifat monolog. Media yang digunakan adalah podium dan dalam tanah. Materi yang disampaikan berupa nasihat, amal untuk menghindari adzab kubur dan mendapat nikmat kubur hingga akhirat. Terdapat keselarasan antara materi dan media.

\section{Pelaksanaan Tabligh Gus Nur}

Gus Nur hadir 2 hari sebelum hari H untuk mempersiapkan kegiatan tabligh bersama panitia. Mubaligh mengadakan doa di lapangan tempat yang akan dijadikan kegiatan tabligh dan Agus, Andi, Holis selaku panitia melakukan penggalian tanah yang posisinya berada di tengah-tengah mubalagh.

Pelaksanaan tabligh di mulai semenjak kehadiran mubaligh di tempat dengan jamaah yang sudah memadati lapangan. Salah satu panitia yang menjadi pembawa acara bernama Ustadz Supyah naik ke atas podium untuk mengucapkan selamat datang kepada mubaligh dan mengawali kegiatan tabligh. Dilanjutkan pembacaan Al-Qur'an oleh Ustadz Farid Abdussalam dan sholawat oleh ibu-ibu majlis ta'lim Nurul Falah.

Mulailah Gus Nur naik ke atas podium dengan para sesepuh berada di belakangnya (diatas podium) dan mengenalkan diri. Sebelum memberikan materi, Gus Nur menyamakan dulu perspektif bahwa mubaligh dan jama'ah sama-sama hamba Allah yang sedang mencari hidayah dan ridha Allah.

Dalam proses komunikasi komunikator harus menggali kepentingan yang sama. Tanpa persamaan kepentingan komunikasi tidak mungkin berlangsung. Keberlangsungan suatu komunikasi dan kemudian terciptanya hasil yang positif, maka komunikator harus menciptakan kepentingan dengan khalayak terutama dalam pesan, teknik dan media.

Proses sebelum ceramah di dalam tanah, Gus Nur dikafani terlebih dahulu oleh panitia, di usung ke keranda dengan dibacakan kalimat tahlil 
oleh jamaah dan dimasukkan ke dalam tanah menghadap kiblat, kayu satu persatu disusun kemudian di adzani dan di tutup dengan tanah (dikubur) layak orang meninggal. Didalam tanah, panitia menempatkan Microfon dan kamera infra merah. Tidak lupa layar di sebelah podium di tempatkan untuk mengetahui keadaan Gus Nur saat menyampaikan ceramah.

Setelah panitia beres menguburkan Gus Nur, dari dalam tanah Gus Nur melanjutkan ceramahnya. Materi yang beliau sampaikan mengenai amalan agar terhindar dari kesulitan hidup. Adapun materinya sebagai berikut:

"Saudaraku, saya sampaikan 5 amalan. Kalau nafas saya kuat saya kupas semuanya. Amalkan 5 amal ini! jika di amalkan anda akan jadi orang yang bahagia, mulia, sukses rohani jasmani.

Siapa di ruangan ini yang banyak deritanya, usahanya selalu gagal. Anda sudah tau amal ini, ilmu dasar ilmu fikih saya hanya menguatkan saja. (Sambil bernafas dan selalu memanggil Allah dan berdoa agar dikuatkan dan ikhlaskan niatnya, ridhoi dakwahnya).

Berhentilah ikhtiar kesana kemari mencari orang pintar, dukun dan lain sebagainya demi mencari solusi maka BERHENTILAH!. Jika anda tidak pernah berhenti dari masalah dan mencari jalan keluar mulai sekarang tegakan shalat 5 waktu berjamaah di masjid sesekali solat di rmah bersama istri. Kalau anda tinggalkan solat Sumpah demi Allah hancur hidupmu. Kenapa engkau cari masalah dan solusi kemana2, cari masjid hamparkan sajadah. Paranormal dan ustadz sekarang berbeda tipiis sama-sama pakai sorban. Ya Allah jadikan orang-orang sepulang dr sini jadi ahli shalat. Mulai dari sekarang saya akan solat biar masalah hidupnya tidak semakin berat.

Mulai sekarang di dalam rumahmu harus ada yang membaca AlQur'an. Kalau rumah sudah tidak ada kumandang Al-Qur'an maka di rumah itu jadi kandangnya setan dan jadi adzab Allah. Kalau tidak bisa ngaji, muliakan Al-Qur'an bilang minta maaf pada Al-Qur'an kalau anda tidak bisa membacanya. Insyaalloh tidak akan ada sihir dan dengki pada hatimu.

Perbanyak lah istighfar sesuai QS. Nuuh ayat 10 yang artinya "Mohonlah ampun kepada Tuhanmu, sesungguhnya Dia adalah maha pengampun". Baca istighfar dan sholawat minimal 90 kali dalam sehari. Setelah sholat subuh 20 kali, dzuhur 20 kali, ashar 20 kali, maghrib 20 kali, dan isya 20 kali maka total sehari 100 kali. Baca istighfar dengan dicicil, di atas kendaraan, ngantri ATM, nunggu istri 
belanja di motor saat di helm baca istighfar dari pada nyanyi-nyanyi maksit. Saudaraku, jangan pernah meremehkan amalan istighfar, silahkan pilih bacaan istighfar yang anda suka; misalnya astaghfirullah robbal baroya astaghfirullah minal khotoya, atau astaghfirullahal'adqim innahu kana ghofaro. Waduh Gus Nur itu kepanjangan sepertinya waktu saya tidak cukup, ya maklum lah saya orang sibuk. Ya kalau masih kepanjangan dipotong saja gak apa-apa, jadi pendek lagi: astaghfirullah, astaghfirullah, astaghfirullah dan seteusnya.

Mulai sekarang jangan pernah engkau menyakiti hati orang tuamu. Siapapun anda, Apapun gelarmu, berapapun penghasilanmu, kalau engkau sakiti hati orang tuamu wallohi engkau akan jadi orang bangkrut nan rugi. Mulai sekarang muliakan orang tua jangan sakiti kalau masih hidup muliakan dengan akhlak. Kalau sudah mati, santuni dengan Al-Fatihah.

Sedekah bapa ibu. Saya ajak bersedekah (para panitia membawa sorban mengelilingi jamaah). Sebelum sedekah anda minta kepada Allah rezeki di permudah, berkah penghasilannya. Uang anda pegang terus baca doa robbighfirli warhamni wazburni warjukni wabdini wa'afini wa' fuanni baru di berikan. Jangan khawatir uang bapa ibu akan di salurkan pada yang membutuhkan sekalipun tidak pada pondok pesantren saya. (Ceramah Gus Nuril)

Pesan yang disampaikan tersebut terdiri dari 3 kategori yaitu aqidah, syari'ah dan akhlak. Pesan aqidah yaitu pesan beriman kepada Allah, Rasul dan hari akhir. Pesan syariah yaitu melaksanakan shalat, membaca alQur'an sholawat dan istighfar, shodaqoh. Pesan akhlak yaitu berbaik hati pada kedua orang tua dan tidak menyakitinya.

Selesai dari ceramah, Gus Nur menutupnya dengan membaca doa. Panitia membongkar kembali tanah dan di angkat Gus Nur ke atas podium. Acara tabligh di tutup dengan mushafahah antara jamaah dan mubaligh.

Setelah kepulangannya, Gus Nur menyatakan bangga kepada masyarakat Ciamis. Penuturannya Ia nyatakan di halaman facebook Gus Nur Ngaji Bareng:

"Kebahagiaan tak terkira ketika dekat dan menyatu dengan hambahamba Allah yang pinggiran, orang-orang kecil, orang-orang lugu, orang-orang yang tulus, tidak ada politik, tidak ada trik, tidak ada kemunafikan, tidak ada kecenderungan mencurangi dan menyakiti. Tidak mengenal bid'ah membid'ahkan, tidak ada nafsu kotor, bahkan tidak sempat berfikir mengkafirkan orang lain, tidak ada merasa 
paling benar, paling suci dan paling alim, yang ada hanya gelora kemesraan lillahi ta'ala. Yang ada hanya Allah dan Rasul.. Allah dan Rasul.. Allah dan Rasul."

Masyarakat di pedesaan merupakan sebuah komunitas kecil yang memiliki ciri-ciri yang khusus dalam pola tata kehidupan, ikatan pergaulan dan seluk beluk masyarakat pedesaan. Salah satu ciri karakteristik masyarakat pedesaan sangat religius. Mereka memegang teguh agama yang diturunkan dari orang tua yang sudah mentradisi. Setiap kegiatan tabligh dan perkumpulan lain mereka ikut berpartisipasi. Dalam hal berprilaku pun, karakter penduduk desa dikenal dengan kesopan santunannya dan sikap silaturahmi terhadap sesama.

\section{Feedback (Umpan Balik) Tabligh Gus Nur}

Feedback yang diterima Gus Nur berbentuk Feedback seketika dan kebanyakan Feedback tertunda. Pada kegiatan tabligh di Ciamis Gus Nur menerima umpan balik seketika yaitu tanggapan dari masyarakat dengan komunikasi personal. Feedback bersifat langsung setelah selesai acara dan feedback menurut kebanyakan masyarakat terutama panitia, tabligh tersebut berjalan lancar dan tidak ada yang memberi tanggapan negatif. Menurut panitia (Siti Qurotul 'Ain) “alhamdulillah sukses tanpa hambatan apapun. Semuanya diberikan kelancaran dan dapat pandangan yang positif dari masyarakat. responnya luar biasa banyak dari perkiraan. Jamaahnya kurang lebih mencapai 5.000 orang, sedangkan snack konsumsi untuk 2.500 0rang" (Data hasil wawancara, 28 Januari 2016).

Adapun sebagian masyarakat luas menggunakan media sosial dan SMS untuk mengutarakan tanggapannya sebagai bentuk feedback atas video dakwah kubur yang di unggah melalui youtobe ataupun facebook "Gus Nur ngaji bareng" ataupun mereka yang sengaja membeli kaset dakwah kubur dan menontonnya. Penulis kutip dari buku Dakwah dari dalam Kubur mengenai tanggapan masyarakat dan jawaban Gus Nur.

Feedback positif datang dari netizen mengatakan:

"Alhamdulillah saya haturkan kepada Allah yang telah memberi Gus Nur kemampuan seperti itu, terima kasih ya Allah dan Gus Nur, suami saya telah lama selingkuh dan menyakiti saya, tiba-tiba kini berubah total setelah melihat kaset Dakwah kuburnya Gus Nur, suami saya jadi takut mati, semoga Allah selalu melindungi Gus Nur sekeluarga" (Gus Nur, 2014: 63).

Kematian itu pasti sesuai firman Allah dalam QS. Al-'Ankabut ayat 
57:

"Setiap yang bernyawa akan merasakan mati. Kemudian hanya kepada Kami kamu dikembalikan” (Depag RI,2014 : 403).

Melihat hal tersebut, mengingat kematian sebagai tiang untuk selalu mendekatkan diri pada Allah dan selalu menjalankan perintah-perintahNya. Salah satu hikmah mengingat kematian adalah menyegerakan taubat. Dengan melihat percontohan Gus Nur dengan memakai kain kafan dan di kubur bagi sebagian masyarakat terketuk hatinya bahwa kematian akan segera menghampiri setiap jiwa.

Adapun feedback negatif yang diterima Gus Nur di antaranya dakwah kubur sihir yakni melebihi akal sehat dan menganiaya diri sendiri, dakwah kubur menyesatkan umat, dakwah kubur bid'ah, dakwah kubur kafir, dakwah kubur syirik

Dari seluruh feedback tersebut Gus Nur memberi jawaban sebagai berikut:

Pro kontra dalam kehidupan sudah menjadi sunnatullah yang menjadi cobaan atau ujian bagi orang yang beriman untuk dinaikkan derajatnya dan dihapuskan dari segala dosa-dosanya. "Saya selalu Haqqul yakin bahwa disaat ada yang mencintai pasti ada pula yang mencaci, disaat ada yang membutuhkan pasti di saat yang sama ada pula yang mengacuhkan. Itulah hidup, dan bahwa kedua-duanya sama-sama datang dari Allah sebagai rahmat atau ujian, juga sebagai bonus gratis menuju derajat yang lebih tinggi" (2004: 10-11).

Gus Nur memaklumi orang yang beranggapan dakwah kubur adalah sihir, karena masih mengandung misteri dan sebuah misteri akan melahirkan banyak pendapat dan argumen.

Dalam al-Qur'an kata “menyesatkan" kurang lebih berjumlah 47 kata yang tersebar di berbagai surat. Salah satunya dalam Al-Qur'an surat Hud ayat 34, "Dan tidaklah bermanfaat kepadamu nasihatku jika aku hendak memberi nasihat kepada kamu, sekiranya Allah hendak menyesatkan kamu, dan Dialah Tubanmu dan kepada-Nya-lah kamu dikembalika."

Saudaraku, ketahuilah pertama kalau saya memang menyesatkan orang, sangat bisa dipastikan bahwa sebelum orang lain tersesat, hakikatnya sayalah orang pertama yang tersesat. Kedua, kesesatan itu pada dasarnya adalah izin Allah dan selebihnya adalah lantaran diri orang itu sendiri. Sekiranya Allah tidak memberikan petunjuk-Nya, tentulah segolongan di antara manusia berusaha keras untuk menyesatkan, tetapi mereka yang menyesatkanmu tidak akan 
Sarah Maesaroh

memberikan bahaya sedikit pun melainkan itu tergantung dirinya sendiri. Ketiga, walaupun disesatkan dengan cara bagaimana pun namun seandainya Allah tak menghendaki, tetaplah mereka senantiasa berada di jalan yang lurus. Sebaliknya tidak akan membawa manfaat apa-apa nasihat saya ini seandainya Dia memang menghendaki terjadinya kesesatan atas diri orang itu (2004: 67).

113:

Jawaban di atas berpusat pada firman Allah dalam QS. An-Nisaa' ayat

"Sekiranya bukan karunia Allah dan rahmat-Nya kepadamu, tentulah segolongan mereka berkeingingan keras untuk menyesatkan dirinya sendiri, dan tidak membahayakanmu sedikitpun. Dan juga karena Allah telah menurunkan kitab dan hikmah kepadamu, dan telah mengajarkan kepadamu apa yang belum engkau ketahui. Karunia Allah yang dilimpahkan kepadamu itu sangat besar" (Depag RI, 2014: 96).

Dalam buku tersebut Gus Nur menegaskan bahwa ia tidak ada niat untuk menyesatkan umat karena dakwah kubur ini merupakan awal kesadaran bukan awal kesesatan.

Bid'ah secara bahasa berarti membuat sesuatu tanpa ada contoh sebelumnya. Mengenai hal tersebut sesuai dengan hadits Nabi Saw. yang diriwayatkan Muslim no 1718:

"Barangsiapa melakukan suatu amalan yang bukan ajaran kami, maka amalan tersebut tertolak."

Dalam sabda beliau mengisyaratkan bahwa setiap amal yang dilakukan hendaknya berada dalam koridor syari'at, maka amalan tersebut tidak tertolak. Namun seluruh kegiatan yang dilakukan kembali kepada hadits Nabi Saw. yang diriwayatkan Bukhari Muslim:ى

"Bahwasanya segala amal perbuatan tergantung pada niat, dan bahwasanya bagi tiap-tiap orang apa yang ia niatkan" (Aminah, 1985: 11).

Niat adalah tolak ukur suatu amalan; diterima atau tidaknya tergantung niat. Niat adalah perkara hati yang urusannya sangat penting, seseorang bisa naik derajat shiddiqin dan bisa jatuh ke derajat yang paling bawah diisebabkan karena niatnya (Marwan, Artikel Muslim).

Pada zaman ini ribuan manusia melakukan dakwah dengan berbagai metode sebagai contoh Sunan Kalijaga menggunakan media seni budaya yakni wayang sebagai alat dakwahnya. Aa Gym melakukan dakwah dengan model baru yang selalu membawa laptop, memakai SMS (Short Message 
Service - Layanan Pesan Singkat) dan email (surat elektronik). Apapun metodenya yang terpenting niatnya menyampaikan ajaran Islam yang telah banyak diperintahkan dalam Al-Qur'an dan Sunnah.

Gus Nur yakin bahwa Rasul tidak akan marah dengan apa yang dia lakukan. "Bagaimanapun juga, saya yang tahu apa yang saya lakukan. Justru dengan cara seperti inilah saya mengekspresikan kecintaan saya kepada Rasul" tegasnya (www.karomah13.com).

Mengkafirkan seorang muslim itu berbahaya bagi dirinya sesuai dengan hadits Nabi Saw.:

"Abu Dzar ra telah mendengar Rasulullah Saw. bersabda: "Siapa yang memanggil seorang dengan kalimat 'hai kafir' atau 'musuh Allah', padahal yang dikatakannya itu tidak demikian, maka akan kembali pada dirinya sendiri” (HR. Bukhari-Muslim).

Dari hadits diatas seorang muslim dilarang menghukumi muslim lainnya dengan perkataan orang kafir karena itu suatu tindakan yang membaca kebinasaan tanpa pahala yang dapat diharapkan darinya dan ini bukan tugas dan kewajiban syariah yang dibebankan kepada setiap pribadi.

Maka menurut Muhammad said yang di kutip Munir (2003: 77) siapa yang menghukum manusia di luar dari apa yang mereka zahirkan dengan alasan bahwa apa yang mereka zahirkan itu baru kemungkinan saja bukan yang sesungguhnya, ada bukti atau tidak, maka jelas dia telah menyalahi AlQur'an dan As-Sunnah.

Dari seluruh feedback negatif yang muncul kembali kepada diri agar memaklumi sehingga dari seluruh tudingan diatas menjadikan diri banyak belajar dan mengokohkan iman agar selalu berjuang di jalan Allah. Rasulullah Saw. adalah sebaik-baiknya contoh dan tauladan yang paling sempurna, namun di dalam berdakwah sering mendapatkan perlakuan yang biadab dari orang-orang kafir tapi selalu dihadapi dengan akhlak yang maha tinggi.

\section{PENUTUP}

Berdasarkan hasil penelitian, maka dapat ditarik kesimpulan: Perencanaan Tabligh Gus Nur yakni mengetahui kondisi khalayak sehingga mengetahui latar belakang dan masalah masyarakat; penentuan pesan sehingga yang sampaikan terarah pada tujuan yang hendak dicapai; penggunaan metode ceramah dengan media dalam kubur sehingga mengundang jamaah lebih dari perkiraan. Pelaksanaan tabligh dimulai dari ceramah dari podium yang dilanjut dengan penggunaan kain kafan, diusung ke keranda, dibacakan 
Sarah Maesaroh

tahlil oleh jamaah dan dikubur. Melanjutkan ceramah dari dalam kubur yang berisi pesan aqidah, syariah dan akhlak. Feedback positif dan negatif yang diterima Gus Nur dianggapnya sebagai sunnatullah. Feedback positif yang diterima berupa ucapan terimakasih kepada Gus Nur dan perubahan akhlak setelah bertaubat. Adapun feedback negatif berupa tudingan sihir, bid'ah, syirik, kafir dan menyesatkan. Dari seluruh pro kontra yang datang ia maklumi karena sehebat Rasulullah saja tidak terlepas dari yang menyanjung dan menentang bahkan membunuh.

Penulis mengemukakan saran kepada Civitas Akademik diharapkan menerapkan pembelajaran kegiatan tabligh yang inovatif demi terciptanya ukhuwah Islamiyah dan saran kepada peneliti selanjutnya, diharapkan dapat mengkaji penelitian lebih lanjut mengenai tabligh Gus Nur dengan penggunaan media dalam kubur ini dari aspek yang lainnya. Seperti pengaruh kepada jamaah, aspek psikologisnya dan lain sebagainya.

\section{DAFTAR PUSTAKA}

Arifin, A. (1994). Strategi Komunikasi: Sebuah Pengantar Ringkas. Bandung: Armico

Arifin, A. (2011). Dakwah Kontemporer. Yogyakarta: Graha Ilmu

Arifin, H. M. (1991). Psikologi Dakwah. Jakarta: Bumi Aksara

Departemen Agama RI. (2014). Al-Qur'an Tajwid dan Terjemah. Bandung: PT Syaamil Cipta Media

Enjang AS, Aliyudin. (2009). Dasar-Dasar Ilmu Dakwah. Bandung: Widya Padjajaran

Fatoni, U. (2003). Kredibiltas Kunci Sukses Muballigh. Bandung: Task Press.

Munir, M. (2006). Manajemen Dakwah. Jakarta: Prenada Media

Ridwan, A. (2011). Ragam Khitobah Ta'tsiriyab: Sebuah Tela'ah Ontologis Ilmu Dakwah: Academic Journal for Homiletic Studies, 5(17) 197 - 232

Shihab, M. Q. (2005). Tafsir al-misbah Pesan dan Keserasian Al-Qur'an Vol. 3. Tanggerang: Lentera Hati

Soebandi, A. (1994). Ilmu Dakwah Pengantar Metodologi. Bandung: Syahida

Suhandang, K. (2014). Strategi Dakwah. Bandung: PT Remaja Rosdakarya

Syukir, A. (1983). Dasar-Dasar Strategi dakwah Islam. Surabaya: Al-Ikhlas. 